\title{
IMPACT OF FEEDING OF LEGUME-CEREAL MIXTURE SILAGES ON DAIRY COW MILK THERMOSTABILITY AND QUALITY
}

\author{
Oto Hanušl, Irena Němečková ${ }^{1}$, Jan Pozdíšek ${ }^{2}$, Igor Huňády ${ }^{3}$, \\ Marcela Klimešovál ${ }^{1}$ Antonín Ponížil ${ }^{3}$, Ondřej Elich ${ }^{1}$, Petr Roubal ${ }^{1}$, \\ Radoslava Jedelská ${ }^{1}$, Jaroslav Kopecký ${ }^{1}$
}

${ }^{1}$ Dairy Research Institute, Ltd., Ke Dvoru 12a, 16000 Prague 6, Czech Republic

${ }^{2}$ AgriResearch Rapotín Ltd., Rapotín, Výzkumníků 267, 78813 Vikýřovice, Czech Republic

${ }^{3}$ Agritec Plant Research Ltd., Zemědělská 16, 78701 Šumperk, Czech Republic

\begin{abstract}
HANUŠ OTO, NĚMEČKOVÁ IRENA, POZDÍŠEK JAN, HUŇÁDY IGOR, KLIMEŠOVÁ MARCELA, PONÍŽIL ANTONÍN, ELICH ONDŘEJ, ROUBAL PETR, JEDELSKÁ RADOSLAVA, KOPECKÝ JAROSLAV. 2018. Impact of Feeding of Legume-Cereal Mixture Silages on Dairy Cow Milk Thermostability and Quality. Acta Universitatis Agriculturae et Silviculturae Mendelianae Brunensis, 66(3): 647-653.

Current changes in climate (increasing drought) and the rise in prices of protein concentrate feed are the reasons for the increasing interest in growing and production and increasing silages from legume-cereal mixtures (LCM) in rations for dairy cows. Another reason is to improve the soil fertility using LCM in crops rotation. The impact of feeding of dairy cows (Czech Fleckvieh and Holstein, 50 herds) on milk quality was monitored (for 3 years) when modifying the roughage feeding rations by additions of LCM silages. Bulk milk samples were tested ( $\mathrm{n}=641$ (15 herds) LCM as experiment and 2,428 (35) as control). LCM was higher in crude protein, lactose, solids non-fat and total microorganisms (from $\mathrm{P} \leq 0.05$ to $\mathrm{P} \leq 0.001$ ). The lower was LCM in the milk freezing point and the urea content $(\mathrm{P}<0.05$ and $\mathrm{P}<0.001)$. The fat content and the somatic cell count were insignificantly different $(\mathrm{P}>0.05)$. There was a significant effect of LCM on milk thermostability $(18.85<20.9$ minutes, $\mathrm{P}<0.05)$. The residues of inhibitory substances in milk were not recorded in the LCM group. The LCM application is a risk-free way of replacement of roughage component part of dairy cow feeding rations with regard to raw milk quality.
\end{abstract}

Keywords: dairy cow, Czech Fleckvieh, Holstein, fat, proteins, lactose, urea, somatic cell count, count of coli-form bacteria

\section{INTRODUCTION}

In 2015, the area of cultivation of legume-cereal mixtures (LCM) grew by $31 \%$. Feeding of silage from LCM is markedly expanding in cattle nutrition in the Czech Republic (CR). The average dry matter content of LCM silages on the total dry matter of these dairy cow feeding rations can be estimated at $15 \pm 5 \%$. The climate changes, such as increasing droughts, as well as rising prices of protein feed concentrates, contribute to this increase. Another reason for cultivation of LCM is the possibility of improving soil fertility by subsidizing of atmospheric nitrogen during crop rotation. Stoddard et al. (2009) reported that legumes are important in world agriculture by providing biologically fixed nitrogen, interrupting the cycle of cereal diseases and contributing to food and feed. Ksiezak and Straniak (2009) evaluated the use of LCM for silages in organic farming. Viscous mixtures were characterized by a higher protein value. Salcedo (2007) reported in a long-term assessment of silage that the highest nitrogen intake in dairy cows was observed in legume-based silages. In comparison to grass or legume monocultures, 
grass + legume mixtures have particular advantages such as more balanced feeding values, increased resource use efficiency and increased herbage production. However, maintaining the optimum legume contents (40-60\% of herbage dry matter) to achieve these benefits remains a major challenge on farms (Phelan et al., 2015). Technical problems in LCM harvesting (rainy weather) and subsequent possible soil pollution of silage can aggravate its microbiological quality, most often by spore microorganisms (bacilli). They can penetrate milk from the stable environment and deteriorate its quality (Andersen and Jensen, 1987, cit. Kratochvíl, 1991). Therefore, the need for studying the effect of increased feeding of LCM silages in dairy cows on the quality of raw milk in practice increases.

The thermostability (TES) of milk (proteins) is a property that can be aggravated by a decrease in its quality. Good TES of raw milk is important in the production of durable products (condensed milk and sterilized UHT, Singh, 2004). The TES in dairy is always related to technologies that lead to products with higher added value. TES is an important parameter in assessing the raw milk quality, particularly in terms of the heat gains that milk is exposed during its processing (Chramostová et al., 2014). This technology test is simple, yet labor-intensive and unpleasant and lengthy. Therefore, the TES data sets for study are of small scale, in number of tens of samples (Chramostová et al., 2014). That is also reason why the data file used here is exceptional for its frequency.

Szterk et al. (2017) were interested in the experimental estimation of impact of maize silages on raw milk and its quality because of practical importance of roughage portion in cow feeding ration. Therefore, the aim of this study was to evaluate the impact of feeding of dairy cows on the TES and raw milk quality on a larger data set by modifying the roughage rations by supplements of LCM silages.

\section{MATERIALS AND METHODS}

\section{Conditions of dairy cow rearing and bulk milk samples}

During the 3 years, 50 herds of dairy cows of Czech Fleckvieh and Holstein breed (36 and 11 and 3 herds of both breeds) which were milked twice a day were included in this survey. Dairy cows were housed in free stables (36) and in binding cowsheds (14). The milking was carried out in the milking parlor (36) in free stables and into pipeline in binding cowsheads (14). The total number of animals covered and monitored was 8,928 (heads). The number of animals in the herds ranged from 4 to 630 (an average of $186 \pm 164$ dairy cows). Animals were fed with roughage feeding rations with LCM silages or without LCM silages (NOLCM) and the herds with feeding of LCM silages for at least 7 months of the year were included in the LCM group. The grazing was applied in the summer feed season in some herds. During the 3-year experimental period 3,069 bulk milk samples were taken at two-weekly or monthly intervals. Additional characteristics of experimental dairy herds are included in Tab. I.

\section{Model dairy cow feeding rations in pilot case study}

A model characteristic of feeding rations was developed to assess possible influencing of milk quality of dairy cows in which LCM silage (mostly pea and barley or pea and triticale) was included into feeding rations as compared to similar non-LCM feeding rations (NOLCM). The average, characteristic feeding rations which are adjusted to the level of cows' milk yield according to the lactation phase are in Tab. II.

The frame, total, average composition of the feeding rations (of course, these were fed with volume modifications according to lactation phase and milk yield) was supplemented with

I: The main and additional group characteristics of herds of dairy cows

\begin{tabular}{lll}
\hline Characteristic/Group & LCM & NOLCM \\
\hline Number of herds in feeding regime & 15 & 35 \\
\hline Average number of dairy cows per herd & $196 \pm 211$ & $183 \pm 149$ \\
Average altitude (m) & $367 \pm 71$ & $343 \pm 67$ \\
Mean of total amount of water precipitation $(\mathrm{mm})$ & $526 \pm 118$ & $562 \pm 149$ \\
Average day delivery of milk to processing into dairy plant $(\mathrm{kg})$ & 3,940 & 4,591 \\
\hline Mean milk yield during standard lactation (305 days/ $\mathrm{kg})$ & 5,688 & 7,005 \\
Mean cow milk yield (kg/day) & $18.65 \pm 8.03$ & $22.97 \pm 7.95$ \\
Number of analyzed bulk milk samples & 641 & 2,428 \\
\hline
\end{tabular}

LCM roughage feeding with legume-cereal mixture silage; NOLCM roughage feeding without legume-cereal mixture silage. 
the consumption of forage cereal concentrates according to the feed tables for the given milk yield OK (cereal concentrate $=$ wheat, calcium carbonate, sodium chloride and sodium hydrogen carbonate 93, 4, 2 and 1\%), BK (protein concentrate = rape seed extract, calprosan and urea 85, 12 and $3 \%$ ) and Corngold plus vitamin and mineral supplements (Unicum and Glycomel). The quality of the applied complete compound feeding rations in the observation can be considered as moderate overall and especially with regard to the roughage feeding portion. Feeding of animals was mostly carried out in the form of total mixed ration (TMR) using a mobile feeding mixer.

\section{Analysis of bulk milk samples}

The samples were preserved with bronopol $(0.03 \%)$ and stored in a refrigerator. Then the samples were transported in cold conditions $\left(<8{ }^{\circ} \mathrm{C}\right)$ to an accredited dairy laboratory (LRM Buštěhrad, ČMSCH a.s.) and analyzed. Values for components (contents) and milk properties were determined: fat (F); crude protein (CP, total $\mathrm{N} \times 6.38$ ); lactose monohydrate (L); total solids (TS); solids non-fat (SNF); urea (U); milk freezing point (MFP); somatic cell count (SCC); total count of mesophilic microorganisms (TCM); count of coli-form bacteria (COLI); milk thermostability (TES); residues of inhibitory substances (RIS, for possible occurrence of antibiotica (drugs) residues and also for possible interference of potential phytoactive substances). In addition, energy (ketose) milk (cow) coefficients F/CP and F/L (Steen et al., 1996; van Knegsel et al., 2010; Hanuš et al., 2013; Manzenreiter et al., 2013) were calculated.

Milk analyzes were performed according to relevant methods with calibrated and controlled analytical techniques according to standard operating procedures. The milk components (F, CP, L, TS, SNF, U) and properties (MFP) were determined by the indirect method of MIR-FT infrared spectroscopy (with interferometer and
Fourier's transformation, in case of MFP with electrical conductivity measurement) CombiFoss FT+ (Foss Electric, Hilleröd, Denmark). The SCC was determined by flow cytometry on the same device. TCM was also determined by flow cytometry using IBC FC (Bentley Instruments, Chaska, Minnesota, USA). The COLI count was determined by plate cultivation method (VRBL agar, $37 \pm 1{ }^{\circ} \mathrm{C}$, abbreviated cultivation period 24-48 hours). The RIS (+/-) were determined by a microbiological (Geobacillus stearothermophilus) inhibition assay (growth at $65^{\circ} \mathrm{C}$ ) with $\mathrm{pH}$ indicator Eclipse 50 (ZEU-INMUNOTEC, Spain). The TES was determined in minutes in non-preserved milk. The time was determined up to visual denaturation (flocculation) of milk proteins when heated in an oil bath at $135^{\circ} \mathrm{C}$. The procedure was carried out with $2.5 \mathrm{ml}$ of milk in a relevant thick-walled glass tube in the Bohemilk Opočno laboratory.

\section{Statistic data treatment and evaluation}

Mean values (arithmetic mean (x), median (m)), variability in the form of standard deviation (sd) and variation coefficient (vx in \%) were calculated for mentioned milk indicators. The indicators (such as SCC, TCM, COLI, TES) with usual absence of normal data frequency distribution (Reneau, 1986; Janů et al., 2007 a; Hanuš et al., 2009) were transformed in logarithmic way $\left(\log _{10}\right)$ to following determination of geometric means (xg) and for possibility of reliable statistic testing with parametric t-test. The differences between milk value means for LCM and NOLCM were tested by the classic t-test (MS Excel, Microsoft, Redmond, Washington, USA).

\section{RESULTS AND DISCUSSION}

\section{Composition and properties of LCM and NOLCM milk}

The parameters of variability and average values of milk components and properties under

II: Model, average, characteristic feeding rations (kg) adjusted to the level of cows milk yield

\begin{tabular}{|c|c|c|c|c|}
\hline In original dry matter & $\begin{array}{c}\text { LCM } \\
30 \text { l of milk }\end{array}$ & $\begin{array}{c}\text { LCM } \\
15 \text { l of milk }\end{array}$ & $\begin{array}{c}\text { NOLCM } \\
30 \text { l of milk }\end{array}$ & $\begin{array}{c}\text { NOLCM } \\
15 \text { lof milk }\end{array}$ \\
\hline Corn silage & 15 & - & 14 & - \\
\hline Grass silage & 7 & 14 & 17 & 19 \\
\hline Triticale silage, dry m. 39\% & 6 & 9 & 7 & 9 \\
\hline Meadow hay & 0.5 & 1.5 & 0.5 & 1.5 \\
\hline OK 2/17 & 4.9 & 3.4 & 4.8 & 3.4 \\
\hline BK 7/16 Calpr. & 2.9 & 0.7 & 3.3 & 0.7 \\
\hline Meadow growth, $18 \%$ dry $m$. & 20 & 20 & 22 & 22 \\
\hline
\end{tabular}




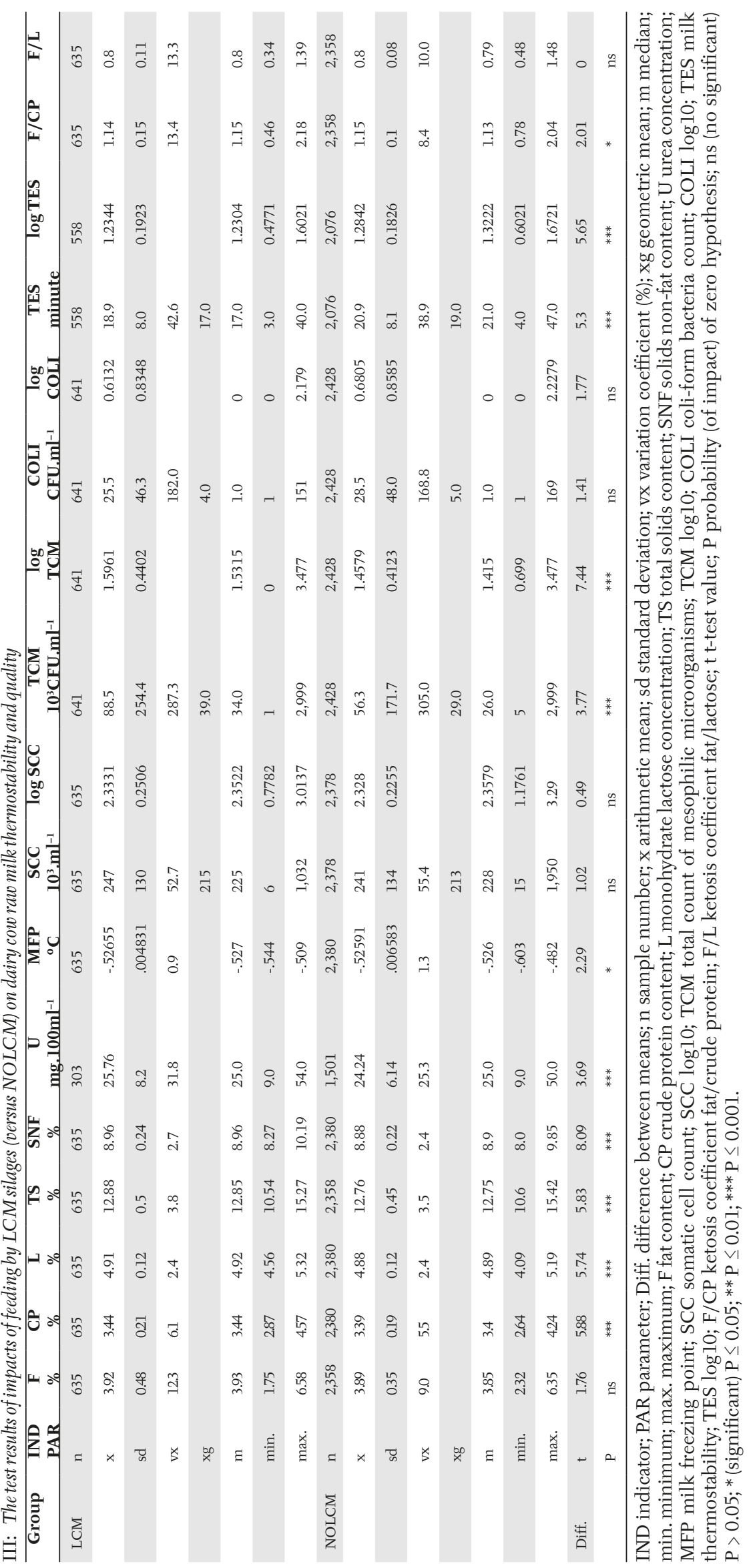


the mentioned conditions of the pilot case study for the LCM and NOLCM group are shown in Tab. III. Lower values of variability (from L and SNF 2.4 to $\mathrm{U} 31.8 \%$ ) were in milk components (F, CP, L, TS, SNF, U) and higher (from SCC 52.7 to TCM 305.0\%) in hygienic indicators (TCM, COLI, SCC). The mean values and their variability of all milk indicators these were in the usual range of relevant reference values for both breeds under conditions in the CR (Janů et al., 2007 a, b; Hanuš et al., 2007, 2009).

TES showed the means 18.85 and 20.9 (LCM and NOLCM, xg 17 and 19) minutes and variability of 42.6 and $38.9 \%$. In other work Chramostová et al. (2014) mentioned mean values which were similar to these but with markedly lower variability. In the study, there were indicated 2 findings $(0.065 \%)$ of RIS (NOLCM). Here it means with the highest probability $(95 \%)$ the occurrence of antibiotics. The value of $0.065 \%$ is comparable with the best European dairy countries in term of quality such as Austria, Switzerland and Bavaria and it is also now approximately on the level which is lower by one third as compared to the CR results. Under the above mentioned monitoring conditions, this indicates a zero risk of LCM silage feeding on possible milk quality deterioration in terms of inhibition. The results support a zero-level risk assessment for a possible false-positive inhibition from possible interference effects of certain bioactive substances such type as phytoinhibitors and phytoestrons.

\section{Differences in milk composition and}

\section{properties between LCM and NOLCM group}

Without a hypothetical explanation, under the mentioned conditions in LCM (Tab. III) there were higher values for CP (Fig. 1), L, SNF and TCB (P from $\leq 0.05$ to $\leq 0.001$ ). The MFP and $U$ mean was lower $(\mathrm{P}<0.05$ and $\mathrm{P}<0.001)$. The $\mathrm{F}$ content and SCC was insignificantly different $(P>0.05)$. The main components including MFP were not markedly affected and basically in favor of LCM, in both TS and SNF it was partly also due to lactose. In the fact, this increase is not practically too severe.

Milk has been seldom evaluated for LCM silage application in a roughage feeding ration for cows. Use of LCM silages in a dairy cow feeding ration as a feed alternative for economic reasons can slightly change the milk composition, improve it occasionally, but it certainly does not lead to a deterioration in the milk quality or the cow reproduction indicators (Hanuš et al., 2016). At assessment of silages including LCM Urbaňski and Brzóska (1996) reported that the milk yield of cows between the $70^{\text {th }}$ and the $150^{\text {th }}$ lactation day, protein and fat in milk did not differ according to the type of fed silage. Kungurov et al. (1981) evaluated lactating cows with a basic feeding ration, where the cereal forage concentrates were partially replaced by silage from pea and oat. There was no significant difference between the groups in milk yield but the substitution group had lower solids in the milk. Emile et al. (2008) reported growth in milk yield in case of inclusion of legumes into silages. Laman et al. (2002) reported that the Use of silage from LCM allowed increased milk yield and reduced use of cereal concentrates. Salcedo (2007) mentioned the highest milk protein of 3.18\% for clover silages in the inclusion of LCM silages into the monitoring but without the relationship of silage variants to fat, protein and urea in milk. The ketosis and energy coefficient of cows and milk F/L did not differ (Tab. III; $0.8=0.8, \mathrm{P}>0.05$ ) and the similar F/CP coefficient was significantly but practically slightly lower for LCM group (Tab. III; $1.14<1.15, \mathrm{P}<0.001)$.

In this evaluation, a significant effect of LCM silages on milk thermostability was registered (Tab. III; Fig. 2; $18.85<20.9$ for xg $17<19$ minutes, $\mathrm{P}<0.05)$. One of the most important factors of thermostability is pH (Singh, 2004; Kailasapathy, 2008). Chládek and Čejna (2005) did not notice the effect of urea concentration increasing in cow's milk on the thermostability of lactoproteins. This result indicated the possibility of TES deterioration through a technological factor in the group of LCM silages.

Although they are significant for TCM (Tab. III; xg 39 LCM > 29 103 CFU.ml-1 NOLCM, P < 0.001), nevertheless, the effects on hygienic indicators do not indicate a marked practical difference in favor of LCM or NOLCM. Theoretically, under deteriorated harvest conditions, the hygienic values of milk for LCM silages could be worse (Andersen and Jensen, 1987, cit. Kratochvíl, 1991). In this case it is so for TCM, but it is not so for COLI $(P>0.05)$. The effect on TCM and COLI is slightly opposite in terms of hygienic evaluation and at COLI against expectations. This is probably due to other interference influences, perhaps the influence of the season when LCM and NOLCM were fed. There was no effect of feeding of LCM silages on SCC (Tab. III; xg 215 LCM and 213 $10^{3} \cdot \mathrm{ml}^{-1}$ NOLCM, $\left.\mathrm{P}>0.05\right)$. From the point of view of the possible interference effects mentioned for hygienic indicators this difference is not essential from a practical point of view.

\section{CONCLUSION}

Possible worsening of the milk indicators such as hygienic in the LCM is basically not marked except for the TES as technology indicator. However, for the most of milk indicators the improvements was noted especially for component indicators. Therefore, the application of LCM silages in feeding rations can be considered as a risk-free, neutral and practically adequate way how to replace a part of the roughage component (and also protein concentrates) of the feeding rations of dairy cows with regard to the raw milk quality under given monitoring conditions. 


\section{Acknowledgement}

This contribution was created with the support of the projects NAZV KUS QJ1510312 and MZE RO 1418. Further the authors thank Mr. director Dipl. Eng. Antonín Kolář, Mrs. Bc. Jitka Haňková and Mr. Ladislav Havlas from Bohemilk Opočno, Mr. Dipl. Eng. Jan Zlatníček, Mrs. Dipl. Eng. Zdeňka Klímová and Mr. Zdeněk Motyčka from ČMSCH a.s. and Mrs. chairman Dipl. Eng. Gabriela Doupovcová and Mr. Dipl. Eng. Pavel Žák from ZD Jeseník for their professional and technical cooperation.

\section{REFERENCES}

EMILE,J.C.,DIAS, F.J.,AL-RIFAI,M.,ROY,P.,LEFAVERDIN,P.2008. Triticale and mixturessilagesforfeeding dairy cows. In: HOPKINS, A., GUSTAFSSON, T., BERTILSSON, J., DALIN, G., NILSDOTTER-LINDE, N. and SPÖRNDLY, E. (Eds.). Biodiversity and animal feed: future challenges for grassland production. Proceedings of the $22^{\text {nd }}$ General Meeting of the European Grassland Federation. Uppsala, Sweden, 9-12 June 2008, pp. 804-806.

HANUŠ, O., FRELICH, J., JANU゚, L., MACEK, A., ZAJÍČKOVÂ, I., GENČUROVÁ, V. and JEDELSKÁ, R. 2007. Impact of different milk yields of cows on milk quality in Bohemian spotted cattle. Acta Veterinaria Brno, 76(4): 563-571.

HANUŠ, O., HEGEDÜŠOVÁ, Z., HOCHMAN, M., KLIMEŠOVÁ, M., HUŇÁDY, I., ROUBAL, P., JEDELSKÁ, R. and KOPECKY, J. 2016. Influence of feeding of legume-cereal mixtures in the silage form on milk quality and cow reproduction [In Czech: Vliv zkrmování luskovino-obilných směsek ve formě siláží na kvalitu mléka a reprodukci krav]. Mlékařské listy-zpravodaj 157, 27(3):3-8.

HANUŠ, O., JANU゚, L., VYLETĚLOVÁ, M. and KUČERA, J. 2009. Research and development of a synthetic quality indicator for raw milk assessment. Folia Veterinaria, 53(2): 90-100.

HANUŠ, O., VYLETĚLOVÁ - KLIMEŠOVÁ, M., CHLÁDEK, G., ROUBAL, P. and SEYDLOVÁ, R. 2013. Metaanalysis of ketosis milk indicators in terms of their threshold estimation. Acta universitatis agriculturae et silviculturae Mendelianae Brunensis, 61(6): 681-1692.

CHLÁDEK, G. and ČEJNA, V. 2005. Effect of urea content on chemical and technological milk indicators in Holstein dairy cows. In: Den mléka 2005, $1^{\text {st }}$ Edition. Prague: TIRA s.r.o.

CHRAMOSTOVÁ, J., VRZÁKOVÁ, Z., NĚMEČKOVÁ, I. and ČURDA, L. 2014. Heat stability of milk and factors influencing it. Mlékařskélisty-zpravodaj, 146: 14-17.

JANU゚, L., HANUŠ, O., BAUMGARTNER, C., MACEK, A. and JEDELSKÁ, R. 2007a. The analysis of state, dynamics and properties of raw cow milk quality indicators in the Czech Republic. Acta Fytotechnica et Zootechnica, 10(3): 74-85.

JANUீ, L., HANUŠ, O., FRELICH, J., MACEK, A., ZAJÍČKOVÁ, I., GENČUROVÁ, V. and JEDELSKÁ, R. 2007 b. Influences of different milk yields of Holstein cows on milk quality indicators in the Czech Republic. Acta Veterinaria Brno, 76(4): 553-561.

KAILASAPATHY, K. 2008. Chemical composition, physical and functional properties of milk and milk ingredients. In: CHANDAN, R. C., KILARA, A. and SHAH, N. P. (Eds.). Dairy Processing and Quality Assurance. John Wiley \& Sons, pp. 75-103.

VAN KNEGSEL, A. T. M., VAN DER DRIFT, S. G. A., HORNEMAN, M., DE ROOS, A. P. V., KEMP, B. and GRAAT, G. A. M. 2010. Ketone body concentration in milk determined by Fourier transform infrared spectroscopy: Value for the detection of hyperketonemia in dairy cows. Journal of Dairy Science, 93:3065-3069.

KRATOCHVÍL, L. 1991. New knowledges about milk bacterial contamination. Náś Chov, 2: 69-71.

KSIEŻAK, J. and STANIAK, M. 2009. Evaluation of legume-cereal mixtures in organic farming as raw material for silage production. Journal of Research and Applied Agricultural Engineering, 54(3): 157-163.

KUNGUROV, Y. N. and GARTVIKH, M. Y. 1981. Silage from slightly cured pea-and-oat mixture in a diet for lactating cows. In: Kormlenie i soderzhanie molochnogo skota v Sibiri, pp. 104-109.

LAMAN, N. A., SHASHKO, K. G., KAPUSTIN, N. K. and ZINOVENKO, A. L. 2002. Nutritive value of silage from mixed cereal-legume crops and its use on rations of lactating cows. Seryya Agrarnykh Navuk, 3: 58-62.

MANZENREITER, H., FÜRST-WALTL, B., EGGER-DANNER, C. and ZOLLITSCH, W. 2013. Zur Eignung des Gehalts an Milchinhaltsstoffen als Ketoseindikator. In: 40. Viehwirtschaftliche Fachtagung. Irdning, 18.-19. 4.2013, pp. 9-19.

PHELAN, P., MOLONEY, A. P., MCGEOUGH, E. J., HUMPHREYS, J., BERTILSSON, J., O'RIORDAN, E. G. and O'KIELY, P. 2015. Forage legumes for grazing and conserving in ruminant production systems. Critical Reviews in Plant Sciences, 34(1/3): 281-326.

RENEAU, J. K. 1986. Effective use of dairy herd improvement somatic cell counts in mastitis control. Journal of Dairy Science, 69(6): 1708-1720.

SALCEDO, G. 2007. Dairy cattle fed silage-based diets. Results of fifteen year experiments in Cantabria (N Spain). Revista pastos, 37(1): 81-127.

STEEN, A., OSTERAS, O. and GRONSTOL, H. 1996. Evaluation of additional acetone and urea analyses, and of the fat-lactose-quotient in cow milk samples in the herd recording system in Norway. Journal of Veterinary Medicine, A43: 181-191. 
SINGH, H. 2004. Heat stability of milk. International Journal of Dairy Technology, 57(2-3): 111-119.

STODDARD, F. L., HOVINEN, S., KONTTURI, M., LINDSTRÖM, K., NYKÄNEN, A., VANHATALO, A., ALAKUKKU, L., HELENIUS, J., PELTONEN-SAINIO, P., PIETOLA, K. and VALKONEN, J. 2009. Legumes in Finnish agriculture: history, present status and future prospects. The Scientific Agricultural Society of Finland. Agricultural Food Sciences, 18(3-4): 191-205.

SZTERK, P., DORSZEWSKI, P., GRABOWICZ, M., PODKÓWKA, L. and ZAREMBA, I. 2017. Productivity, milk composition and milk quality of cows fed maize silage covered with oxobiodegradable film. Journal of Central European Agriculture, 18(4): 762-772.

URBAŇSKI, A. and BRZÓSKA, F. 1996. Legume-cereal forage mixtures for silage. 2. Nutritive value of silage for dairy cows. Journal of Animal and Feed Sciences, 5(2): 117-126.

\section{Appendix}

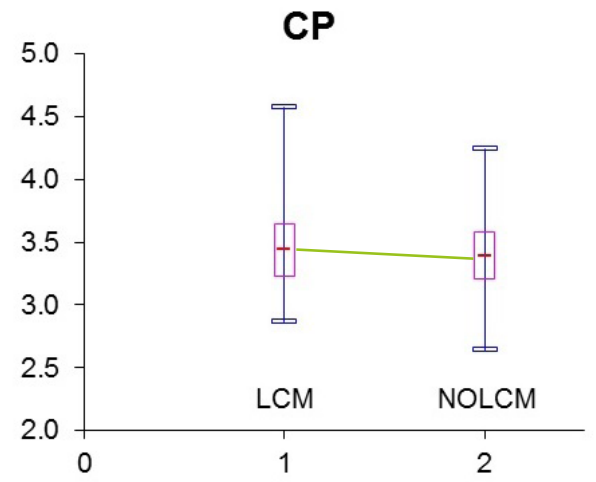

1: The influence of feeding by LCM (versus NOLCM) silages on crude protein content (CP; \%) in raw cow's milk $(\mathrm{P}<0.001)$

LCM roughage feeding with legume-cereal mixture silage; NOLCM roughage feeding without legume-cereal mixture silage. Construction of box graph: the file median (the central short horizontal line); the top edge of $1^{\text {st }}$ and $3^{\text {rd }}$ quartile (the tetragon); the variation range as difference between maximum an minimum (the vertical line).

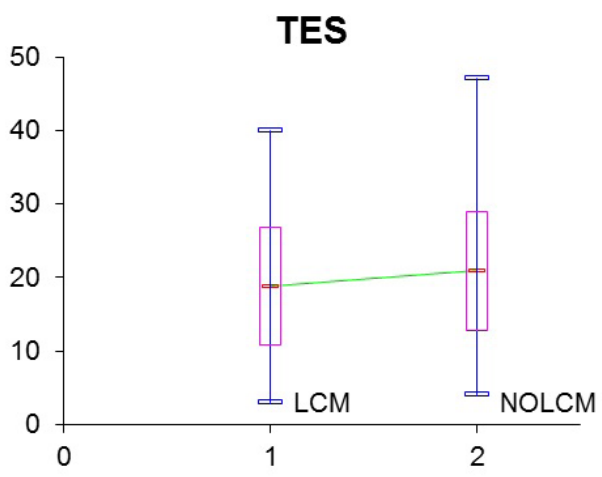

2: The influence of feeding by LCM (versus NOLCM) silages on thermostability (TES; minute) of raw cow's milk $(\mathrm{P}<0.001)$

Oto Hanuš: hanus.oto@seznam.cz

Contact information

Irena Němečková:nemeckova@milcom-as.cz

Jan Pozdíšek: jan.pozdisek@seznam.cz

Igor Huňády: hunady@agritec.cz

Marcela Klimešová: marcela.vyletelova@seznam.cz

Antonín Ponížil: ponizil@agritec.cz

Ondřej Elich: elich@milcom-as.cz

Petr Roubal: roubal@milcom-as.cz

Radoslava Jedelská:radka.jedelska@seznam.cz

Jaroslav Kopecký: jaroslav.kopecky@email.cz 